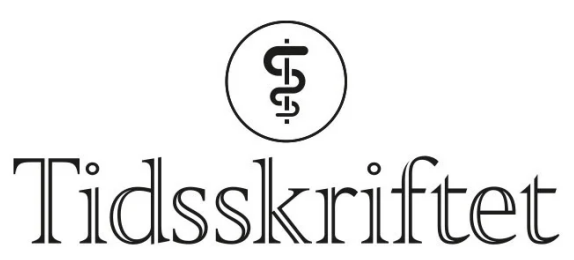

DEN NORSKE LEGEFORENING

\title{
Medikamenter som kan utløse og forverre myasthenia gravis
}

\author{
LEGEMIDLER I PRAKSIS
}

\section{AHMED ELSAIS}

Ahmed Elsais (f. 1965) er spesialist i nevrologi.

Forfatter har fylt ut ICMJE-skjemaet og oppgir ingen interessekonflikter.

Email: ahmed.elsais@medisin.uio.no

Nevrologisk avdeling

Oslo universitetssykehus, Rikshospitalet

og

Avdeling for klinisk medisin

Universitetet i Oslo

\section{TRINE HAUG POPPERUD}

Trine Haug Popperud (f. 1975) er lege i spesialisering i nevrologi.

Forfatter har fylt ut ICMJE-skjemaet og oppgir ingen interessekonflikter. Nevrologisk avdeling

Oslo universitetssykehus, Rikshospitalet

og

Avdeling for klinisk medisin

Universitetet i Oslo

\section{ØYVIND MELIEN}

Øyvind Melien (f. 1958) er spesialist i klinisk farmakologi og seksjonsoverlege. Forfatter har fylt ut ICMJE-skjemaet og oppgir ingen interessekonflikter. Avdeling for medisinsk utstyr og legemidler Helsedirektoratet

\section{EMILIA KERTY}

Emila Kerty (f. 1948) er spesialist i nevrologi og i øyesykdommer, overlege og professor. Forfatter har fylt ut ICMJE-skjemaet og oppgir ingen interessekonflikter.

Nevrologisk avdeling

Oslo universitetssykehus, Rikshospitalet

og

Avdeling for klinisk medisin

Universitetet i Oslo 


\section{Behandling av pasienter med myasthenia gravis er en}

spesialistoppgave, men alle leger vil kunne komme i kontakt med pasientgruppen i forbindelse med andre tilstander. En rekke medikamenter som brukes for andre samtidige sykdommer, kan forverre muskelsvakheten eller utløse en myasteniliknende tilstand. Vi gir her en oversikt over de vanligste medikamenter som bør brukes med forsiktighet hos disse pasientene.

Myasthenia gravis er en autoimmun sykdom som hemmer den nevromuskulære signaloverføringen ved at det dannes autoantistoffer rettet mot acetylkolinreseptorer (1) . Behandling er en spesialistoppgave. Den primære medikamentelle behandlingen er basert på bruk av kolinesterasehemmere, f.eks. pyridostigmin, som ved å hemme nedbrytingen $\varnothing$ ker mengden av tilgjengelig acetylkolin og dermed reduserer symptomene. Det er ofte nødvendig å kombinere dette med steroidbehandling og immunsuppressiver (므).

Medikamentell behandling av annen samtidig sykdom hos pasienter med myasthenia gravis kan være krevende. Det er flere medikamenter som kan forverre muskelsvakheten hos en pasient med kjent sykdom. Enkelte medikamenter kan demaskere en latent subklinisk myasthenia gravis eller utløse en forbigående myasteniliknende tilstand (3).

Vi har fått mange spørsmål fra pasienter, deres primærleger og spesialister i ulike disipliner om bruk av legemidler ved annen sykdom hos personer med myasthenia gravis. Dette synliggjør et behov for å sammenfatte hovedpunkter om legemiddelbruken der disse pasientene har en annen samtidig sykdom. Nedenfor gir vi en oversikt over de vanligste medikamentene som kan utløse eller forverre myasthenia gravis (fig 1). Disse må brukes med forsiktighet og under nøye oppfølging eller unngås helt.

\begin{tabular}{|c|c|}
\hline Kontraindisert & D-penicillamin \\
\hline Bør unngås & $\begin{array}{l}\text { Interferon } \\
\text { Curare } \\
\text { Botulinumtoksin }\end{array}$ \\
\hline Gir hyppig forverring & $\begin{array}{l}\text { Aminoglykosider } \\
\text { Makrolider } \\
\text { Enkelte antiepileptika } \\
\text { Magnesiumsulfat }\end{array}$ \\
\hline Kan forverre tilstanden & $\begin{array}{l}\text { En del antibiotika } \\
\text { Steroider (ved hypokalemi) } \\
\text { Betablokkere } \\
\text { Ca-antagonister } \\
\text { Diuretika } \\
\text { Statiner } \\
\text { Litium }\end{array}$ \\
\hline
\end{tabular}

Figur 1 De vanligste medikamentene som kan utløse eller forverre myasthenia gravis Medikamenter kan påvirke den nevromuskulære transmisjonen ved ulike virkningsmekanismer. Enkelte stoffer har en presynaptisk effekt og forstyrrer aksjonspotensialet i nerveendene, andre virker i synapsen ved å degradere acetylkolin eller postsynaptisk ved å forstyrre oppbygging av aksjonspotensialet (fig 2). 


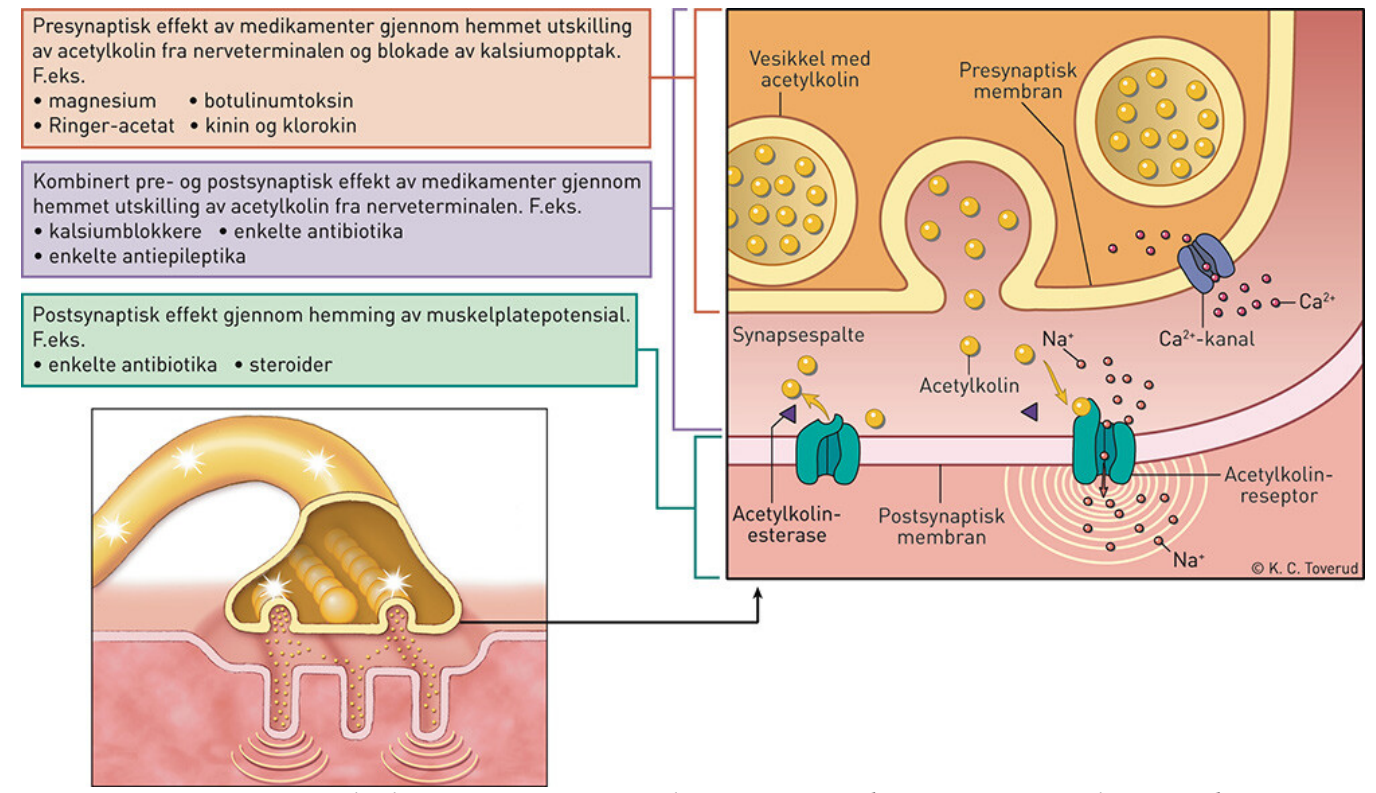

Figur 2 Den nevromuskulære synapse. Depolarisering av den presynaptiske membran frigjør acetylkolin, som aktiverer acetylkolinreseptorer i muskelcellen. Medikamenter kan påvirke acetylkolinsekresjonen og effekten av acetylkolin på muskelcellen Ut fra vår erfaring fremviser pasienter med velregulert myasthenia gravis en gradvis økende svakhet ved en eventuell medikamentutløst reaksjon. Symptomatiske myasthenia gravispasienter med generalisert sykdom er mest utsatt for legemiddelindusert forverring.

Denne oversikten er basert på et litteratursøk i PubMed. Vi gjorde et skjønnsmessig utvalg av artikler ut fra våre egne erfaringer på feltet, med vekt på vanlig brukte medikamenter.

\section{Kontraindiserte medikamenter}

Av vanlig brukte medikamenter er kun D-penicillamin kontraindisert ved myasthenia gravis. D-penicillamin brukes ved behandling av flere kroniske autoimmune sykdommer og som kobberkelator ved Wilsons sykdom (4.). Midlet kan indusere en myasteniliknende tilstand eller demaskere maysthenia gravis.

En penicillaminindusert myasteni er oftest begrenset til okulære symptomer, som forsvinner innen 2-6 måneder etter seponering (5). 90 \% av disse pasientene får en forbigående stigning i nivået av antistoffer mot acetylkolinreseptorer (ㅁ$)$.

\section{Medikamenter som bør brukes med forsiktighet}

\section{STATINER}

Statiner er mye brukte legemidler. Det er kjent at de kan utløse muskulære bivirkninger som myalgi og myopati (7.). Det er også beskrevet statinindusert myasthenia gravis og forverring av myasteniske symptomer ved bruk av statiner (므).

I en retrospektiv studie basert på 170 pasienter med myasthenia gravis, hvorav 54 brukte statiner, rapporterte seks (11\%) om klar forverring innen fire måneder etter oppstart av statinbehandling (9.). Hos tre av disse ble det nødvendig med immunoglobulinbehandling intravenøst. Pasienter med myasthenia gravis bør vurderes for behandling med statiner på lik linje med andre, men de bør få grundig informasjon, og ved eventuell økende muskelsvakhet bør statinet seponeres. Alternativt kan andre typer statiner vurderes (10 $)$.

\section{MAGNESIUM}

Hypermagnesemi kan forverre myasthenia gravis. Mekanismen antas å være interferens med nevromuskulær transmisjon gjennom hemming av acetylkolinfrigjøring og blokade av kalsiumopptak i motornevronterminalene (1ㅡ)-(13). Magnesium brukes som 
medikament i seg selv, men finnes også i magnesiumholdige medikamenter som antacider og laksativer. Magnesiumsulfat $\left(\mathrm{MgSO}_{4}\right)$ benyttes ved høyt blodtrykk og muskelkramper, spesielt ved preeklampsi og eklampsi. Dette kan føre til forverring av myasthenia gravis, da dosen er stor og gis intravenøst. Minste effektive dose bør vurderes hos myasthenia gravispasienter (14).

Ringer-acetat inneholder magnesium, og bør av samme grunn unngås hvis det er behov for intravenøs væsketilførsel (15).

\section{BLODTRYKKSMEDIKAMENTER}

Betablokkere kan demaskere en subklinisk myasthenia gravis eller forverre tilstanden hos en myastenisk pasient $(\underline{16})$. Propranolol er mest kjent for dette. Timololholdige øyedråper i glaukombehandling kan ha samme virkning, muligens noe mildere, ettersom disse brukes lokalt (17.). Kalsiumkanalblokkere kan gi muskelsvakhet og eventuell respirasjonssvikt som følge av redusert nevromuskulær transmisjon grunnet redusert acetylkolinfrigjøring og/eller postsynaptisk curareliknende effekt (묘).

Forverring av myasthenia gravis ved bruk av diuretika er mest sannsynlig betinget i en ledsagende hypokalemi (19.). Kaliumsparende diuretika som spironolakton er å foretrekke. Elektrolytter må kontrolleres regelmessig ved slik behandling.

\section{ANTIINFEKTIVER}

Av antibiotika er særlig aminoglykosider kjent for å hemme den nevromuskulære overføringen, med muskelsvakhet som følge (3). Effekten er doseavhengig.

Aminoglykosider kan påvirke acetylkolinfrigjøringen (f.eks. tobramycin) eller blokkere actetylkolinbindingen til reseptorene (f.eks. netilmycin). Det er også kasuistikker om myasteniforverring grunnet makrolider, særlig det nær beslektede ketolidet telitromycin

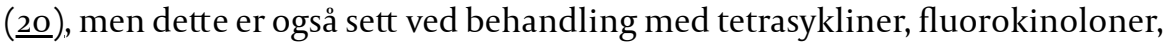
sulfonamider og penicillin (3).

Det beste rådet når det gjelder antibiotika, er å velge det midlet som er best egnet ved den aktuelle sykdom og følge pasienten nøye med tanke på eventuell økende muskelsvakhet.

Kinin og klorokin virker presynaptisk ved å redusere danning og frigjøring av acetylkolin.

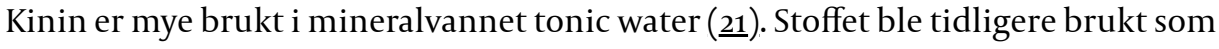
diagnostisk test for myasthenia gravis (3), og små mengder kan føre til forverring av muskelsvakheten hos en ustabil myastenipasient.

Interferon- $\alpha$, som brukes i behandling av blant annet hepatitt og leukemi, kan indusere

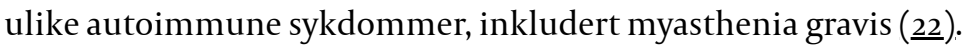

\section{STEROIDER}

De fleste pasienter med myasthenia gravis bruker steroider som immunsuppressiv behandling. Steroidbehandling kan føre til hypokalemi (23) og dermed muskelsvakhet. Oppstart med høye doser steroider kan gi alvorlige bivirkninger, med respirasjonspåvirkning og myastenisk krise. Vi anbefaler derfor å starte med lav dose og trappe opp langsomt.

\section{MEDIKAMENTER MED HOVEDVIRKNING PÅ NERVESYSTEMET}

Flere antiepileptika, som fenytoin, barbiturater, etosuksimid, karbamazepin og benzodiazepiner (24).), påvirker den nevromuskulære signaloverføringen både pre- og postsynaptisk og forårsaker økt svakhet hos myastenipasienter. Nylig er det også beskrevet at gabapentin og pregabalin kan forverre tilstanden hos pasienter med myasthenia gravis (25).

Behandlingen bør være individualisert og følges nøye opp. Det er ikke vist effekt av valproat og topiramat på myasthenia gravis, og det foreligger ikke rapporter om nyere antiepileptika. Benzodiazepiner er muskelrelakserende og kan føre til økt muskelsvakhet (므). Baklofen er ikke kontraindisert hos myastenipasienter, men kan gi økt asteni og bør brukes med forsiktighet (207.). 
Det er rapportert at litium kan demaskere eller forverre myasthenia gravis. Litium kan også forlenge effekten av nevromuskulære blokkere. Ved behandling av bipolar affektiv lidelse bør man fortrinnsvis velge et annet preparat, ellers må pasienten følges nøye opp. De

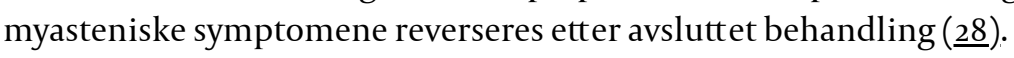

Botulinumtoksin brukes mot muskelspasmer, blant annet ved fokal dystoni, men også i kosmetisk behandling. Toksinet hemmer acetylkolinproduksjon og -frisetting fra nerveendene. Selv om effekten hovedsakelig skal være lokal ved injeksjonsstedet, er det rapportert systemiske bivirkninger (29.). Botulinumtoksin er kontraindisert hos pasienter med kjent defekt i nevromuskulær overføring. Det må foreligge en klar indikasjon og stabil myasthenia gravis, og minste effektive dose må vurderes. Bulbære symptomer må være absolutt kontraindikasjon.

Akutt myastenisk forverring er rapportert i forbindelse med bruk av jodholdige kontrastmidler (25) Mekanismen er ikke kjent. Nyere kontrastmidler fører til langt færre komplikasjoner (14).

ANESTETIKA OG ANALGETIKA

Mange myasthenia gravis-pasienter har utviklet myastenisk krise i forbindelse med kirurgi og anestesi. Pasienter med ustabile symptomer som får høye doser

acetylkolinesterasehemmere er spesielt utsatt for narkoseassosierte forverringer. Pasienter med myasthenia gravis må stabiliseres før planlagt kirurgi, alternativt forbehandles med plasmaferese eller intravenøs immunglobulin et par uker før inngrepet. Det er viktig å være klar over at også velregulerte myastenipasienter kan ha økt sensitivitet og forlenget effekt av muskelrelakserende medikamenter. Fortrinnsvis gis $50 \%$ av standard dose av perifert virkende muskelrelakserende midler til pasienter med myasteni (3ㅇ).

Det er usikkert om det er risiko for forverring av myasthenia gravis etter lokalbedøvelse med lidokain og procaine (31,32). Ved regional bedøvelse og lokalbedøvelse til pasienter med stabil sykdom kan standard dosering gis, men hos dårlig regulerte pasienter må man nøye vurdere indikasjon og dose (2‥).

Smerte er et belastende symptom og kan i seg selv være årsak til myastenisk forverring (33). Ikke-steroide antiinflammatoriske midler og paracetamol er å foretrekke som smertestillende. Opioider påvirker ikke den nevromuskulære transmisjonen direkte, men den respiratorisk dempende effekten må observeres. Samtidig bruk av kolinesterasehemmere forlenger og forsterker effekten av opioider, derfor kan lavere opioiddoser være tilstrekkelig. Ved behov for smertestillende intramuskulært eller intravenøst anbefales små og hyppige doser av raskt og kortvirkende opioid fremfor de lengevirkende.

VAKSINER

Dette kan bli aktuelt i forbindelse med rutinemessige vaksinasjonsprogrammer, hos eldre og andre med kroniske sykdommer og ved utenlandsreiser. Vaksiner er antigener som kan trigge immunsystemet og gi sykdomsforverring. Levende vaksiner bør kun gis ved meget velbegrunnede indikasjoner. Inaktiverte vaksiner eller toksiodvaksiner fører vanligvis ikke til forverring av myasteni. Influensavaksiner kan gis til stabile myasthenia gravis-pasienter (34).

\section{Konklusjon}

En rekke medikamenter kan virke ugunstig på nevromuskulær overføring. Men med unntak av penicillinamin er ingen medikamenter absolutt kontraindisert hos myasthenia gravis-pasienter. Primært bør man velge det medikamentet som er best egnet til behandling av den aktuelle sykdom. Det er meget viktig at pasientens tilstand følges nøye. Ved tegn på økende muskulær svakhet bør medikamentbytte overveies. 
Flere medikamenter kan forverre myasthenia gravis eller demaskere latent sykdom Symptomatiske myasthenia gravis-pasienter med generalisert sykdom er særlig utsatt for legemiddelindusert forverring

Pasientene må behandles når det er nødvendig, men ved forskriving av nytt medikament er det viktig å være oppmerksom på mulig forverring av muskelsvakheten

Dersom symptomer på myastenisk forverring oppstår, bør nystartet behandling avbrytes

\section{LITTERATUR}

1. Lindstrom JM, Seybold ME, Lennon VA et al. Antibody to acetylcholine receptor in myasthenia gravis. Prevalence, clinical correlates, and diagnostic value. Neurology 1976; 26: 1054-9. [PubMed] [CrossRef]

2. Gilhus NE. Myasthenia and the neuromuscular junction. Curr Opin Neurol 2012; 25: 523-9.

[PubMed] [CrossRef]

3. Pascuzzi RM. Medications and myasthenia gravis (a reference for health care professionals). www.myasthenia.org/LinkClick.aspx?fileticket=JuFvZPPq2vg\%3d. 2002 (25.11.2012).

4. Walshe JM. Penicillamine neurotoxicity: an hypothesis. ISRN Neurol 2011; 2011: 464572.

5. Drosos AA, Christou L, Galanopoulou V et al. D-penicillamine induced myasthenia gravis: clinical, serological and genetic findings. Clin Exp Rheumatol 1993; 11:387-91. [PubMed]

6. Fried MJ, Protheroe DT. D-penicillamine induced myasthenia gravis. Its relevance for the anaesthetist. Br J Anaesth 1986; 58: 1191-3. [PubMed] [CrossRef]

7. Tomaszewski M, Stçpien KM, Tomaszewska J et al. Statin-induced myopathies. Pharmacol Rep 2011; 63: 859-66. [PubMed]

8. Elsais A, Lund C, Kerty E. Ptosis, diplopia and statins: an association? Eur J Neurol 2008; 15: e92-3. [PubMed] [CrossRef]

9. Oh SJ, Dhall R, Young A et al. Statins may aggravate myasthenia gravis. Muscle Nerve 2008; 38: 11017. [PubMed] [CrossRef]

10. Pasutharnchat N, Phanthumchinda K. Statin-associated myasthenic weakness. J Med Assoc Thai 2011; 94: 256-8. [PubMed]

11. Mueksch JN, Stevens WA. Undiagnosed myasthenia gravis masquerading as eclampsia. Int J Obstet Anesth 2007; 16:379-82. [PubMed] [CrossRef]

12. Catanzarite VA, McHargue AM, Sandberg EC et al. Respiratory arrest during therapy for premature labor in a patient with myasthenia gravis. Obstet Gynecol 1984; 64: 819-22. [PubMed]

13. Bashuk RG, Krendel DA. Myasthenia gravis presenting as weakness after magnesium administration. Muscle Nerve 1990; 13: 708-12. [PubMed] [CrossRef]

14. Pascuzzi RM. Drugs and toxins associated with myopathies. Curr Opin Rheumatol 1998; 10: 511-20. [PubMed] [CrossRef]

15. Nastuk WL. Mechanisms of neuromuscular blockade. Ann N Y Acad Sci 1971; 183: 171-82. [PubMed] [CrossRef]

16. Herishanu Y, Rosenberg P. Letter: beta-Blockers and myasthenia gravis. Ann Intern Med 1975; 83: 834-5. [PubMed]

17. Verkijk A. Worsening of myasthenia gravis with timolol maleate eyedrops. Ann Neurol 1985; 17: 211-2. [PubMed] [CrossRef]

18. Dale RC, Schroeder ET. Respiratory paralysis during treatment of hypertension with trimethaphan camsylate. Arch Intern Med 1976; 136: 816-8. [PubMed] [CrossRef]

19. Jenkins RB, Witorsch P, Smyth NP. Aspects of treatment of crisis in myasthenia gravis. South Med J 1970; 63: 1127-30. [PubMed] [CrossRef]

20. Bertrand D, Bertrand S, Neveu E et al. Molecular characterization of off-target activities of telithromycin: a potential role for nicotinic acetylcholine receptors. Antimicrob Agents Chemother 2010; 54: 5399-402. [PubMed] [CrossRef]

21. Bateman DN, Dyson EH. Quinine toxicity. Adverse Drug React Acute Poisoning Rev 1986; 5: 215-33. [PubMed] 
22. Stübgen JP. Interferon alpha and neuromuscular disorders. J Neuroimmunol 2009; 207:3-17. [PubMed] [CrossRef]

23. Critchley M, Herman KJ, Harrison M et al. Value of exchangeable electrolyte measurement in the treatment of myasthenia gravis. J Neurol Neurosurg Psychiatry 1977; 40: 250-2. [PubMed] [CrossRef]

24. Rasmussen M. Carbamazepine and myasthenia gravis. Neuropediatrics 2004; 35: 259. [PubMed] [CrossRef]

25. Sheen VL, Ohaegbulam C, Rencus T et al. Gabapentin-induced exacerbation of myasthenia gravis. Muscle Nerve 2010; 42:149. [PubMed] [CrossRef]

26. Dillon FX. Anesthesia issues in the perioperative management of myasthenia gravis. Semin Neurol 2004; 24: 83-94. [PubMed] [CrossRef]

27. Haroutiunian S, Lecht S, Zur AA et al. The challenge of pain management in patients with myasthenia gravis. J Pain Palliat Care Pharmacother 2009; 23: 242-6o. [PubMed] [CrossRef]

28. Alevizos B, Gatzonis S, Anagnostara Ch. Myasthenia gravis disclosed by lithium carbonate. J Neuropsychiatry Clin Neurosci 2006; 18: 427-9. [PubMed] [CrossRef]

29. Bakheit AM, Ward CD, McLellan DL. Generalised botulism-like syndrome after intramuscular injections of botulinum toxin type A: a report of two cases. J Neurol Neurosurg Psychiatry 1997; 62: 198. [PubMed] [CrossRef]

30. Blichfeldt-Lauridsen L, Hansen BD. Anesthesia and myasthenia gravis. Acta Anaesthesiol Scand 2012; 56:17-22. [PubMed] [CrossRef]

31. Hirst GD, Wood DR. On the neuromuscular paralysis produced by procaine. Br J Pharmacol 1971; 41: 94-104. [PubMed] [CrossRef]

32. Katz RL, Gissen AJ. Effects of intravenous and intra-arterial procaine and lidocaine on neuromuscular transmission in man. Acta Anaesthesiol Scand Suppl 1969;36:103-13. [PubMed] [CrossRef]

33. Thanvi BR, Lo TC. Update on myasthenia gravis. Postgrad Med J 2004; 80: 690-70o. [PubMed] [CrossRef]

34. Zinman L, Thoma J, Kwong JC et al. Safety of influenza vaccination in patients with myasthenia gravis: a population-based study. Muscle Nerve 2009; 40: 947-51. [PubMed] [CrossRef]

Publisert: 5. februar 2013. Tidsskr Nor Legeforen. DOI: 10.4045/tidsskr.12.0624

Mottatt 18.5. 2012, første revisjon innsendt 26.9. 2012, godkjent 3.12. 2012. Medisinsk redaktør Kristin Viste.

(C) Tidsskrift for Den norske legeforening 2023. Lastet ned fra tidsskriftet.no 26. april 2023. 